\title{
Christelike gesindheid en politieke protes
}

\author{
J M Vorster \\ Skool vir Kerkwetenskappe \\ Noordwes-Universiteit (Potchefstroomkampus)
}

\begin{abstract}
Christian attitude and political protest

In Christian ethics the issue of protest has always been a widely discussed theme. Notwithstanding, the development of constitutional democracies all over the world, the topic has become even more prominent especially as it relates to the following issues: the position of minority groups in majority governments and the freedom of individuals to maintain a certain value system in various spheres of authority. This article discusses the nature of a Christian perspective on political protest and the role such Christian attitude can play. In this regard special reference is made to the strategies of armed resistance, civil disobedience and external pressure. The implementation of the classic idea of "uis ad bellum" is questioned on grounds of the current existence of weapons of mass destruction. Norms are formulated for the responsible use of civil disobedience and external pressure to promote freedom of choice and expression in a peaceful and constructive way.
\end{abstract}

\section{INLEIDING}

Gesindheid is 'n belangrike faktor in die mens se etiese handelinge. 'n Handeling is moreel reg wanneer dit met 'n goeie gesindheid en 'n goeie bedoeling aangepak word en gerig is op 'n goeie uitkoms (Hauerwas, 1981:129). 'n Verkeerde gesindheid kan nie 'n goeie bedoeling en 'n goeie uitkoms tot gevolg hê nie. Die gesindheid waarmee 'n handeling uitgevoer word, bepaal tot 'n groot mate die etiese of onetiese aard van die handeling. Die gesindheid van 'n Christen moet 'n weerspieëling wees van die gesindheid van Christus (Fil 2:5). Oor Christelike gesindheid is reeds in 'n vorige publikasie meer uitvoerig geskryf en die resultate daarvan word hier slegs saamgevat (Vorster 2004:48). In genoemde artikel is tot die konklusie gekom dat 'n Christen se roeping om die gesindheid van Christus in sy eie etiese handelinge uit te druk, op die volgende neerkom: 


\section{Christelike gesindheid en politieke protes}

- $\quad$ Medelye. Dit beteken om menslik, medelydend en diensbaar te wees aan mense in hulle soeke na regverdigheid, menswaardigheid en respek.

- Rentmeesterskap. Dit beteken om om God te dien as sy diensknegte en rentmeesters en sodoende ook die gemeenskap te dien deur 'n vreedsame soeke na regverdige sosiale strukture en 'n aanvaarbare morele orde.

- $\quad$ Offervaardigheid. Dit beteken om gewillig te wees om Christus na te volg deur selfoorgawe aan die saak van die koninkryk van God binne verskillende samelewingsverbande.

- Gehoorsaamheid. Dit beteken om aan die wil van God gehoorsaam te wees soos God se wil in sy Wet en in die Skrif uitgedruk word.

Kortom, die gesindheid van 'n Christen weerspieël die gesindheid van 'n gehoorsame dienskneg van God.

Hoe moet 'n Christen hierdie gesindheid uitstraal binne die raamwerk van 'n onregverdige gesagsisteem of in 'n sisteem waarin gehoorsaamheid aan die sisteem en onderdanigheid daaraan Christelike etiese norme in gedrang bring? Hoe moet ' $n$ Christen 'n dienskneggestalte vertoon in sulke omstandighede? Mag kinders dan die gesag van hulle ouers in bepaalde opsigte verwerp? Mag mediese personeel die reëls van gesondheidsowerhede verontagsaam soos byvoorbeeld om die positiewe MIV-status van 'n pasiënt aan 'n huweliksgenoot bekend te maak? Mag minderheidsgroepe weier om belasting te betaal as hulle oortuig is dat hulle taal en kulturele etos deur bepaalde owerheidshandelinge bedreig word? Mag verset lei tot ontwrigtende optrede? Op watter wyse mag hierdie reaksies geskied? Wanneer is geweld geregverdig? Vrae soos die volgende kan egter ook van die gesagsdraer se kant gevra word: In watter mate mag selfoorgawe en diensvaardigheid van onderdane verwag word as hulle regte beperk of opgehef word ter wille van staatsveiligheid? ${ }^{1}$ Genoemde vrae is vandag weer

\footnotetext{
${ }^{1}$ Na die terroristeaanvalle op die Wêreldhandelsentrum in New York op 11 September 2001 het die regering van die VSA verskeie maatreëls daargestel om die privaatheid van die individu te beperk ter wille van staatsveiligheid. Sulke beperkings is ook dikwels toegepas deur die Suid-Afrikaanse regering in die tydperk van burgeroorlog voor 1990. Die nuwe SuidAfrikaanse Grondwet (1996) bevat ook 'n klousule wat bepaal dat bepaalde vryhede, onder andere die vryheid van godsdiens tydens 'n noodtoestand opgehef kan word (RSA 1996). Die regte van individue kan dus opgehef word - 'n maatreël wat staatstotalitarisme moontlik maak. Sodanige owerheidshandelinge inisieer maklik gesagsmisbruik waarin die burgery onderwerp word aan die magsarrogansie van 'n amptenary.
} 
aktueel vanweë die nuwe vorms van terreur wat internasionaal voorkom en vrede in baie gemeenskappe bedreig. Vir die Christelike etiek is die debat hieroor belangrik - veral omdat kragdadige optrede, aggressie en selfs geweld in die onlangse verlede in die Christelike etiek as legitieme strategieë vir verandering geromantiseer is (kyk Gutierrez 1973:48; Cone 1975:217; Fierro 1977201). Kan hierdie keuses nog in die huidige konteks en tydsgewrig Christelik-eties aanvaar word? Sodanige vrae en kwessies het alles te make met die waarde wat geheg word aan Christelike gesindheid in sulke omstandighede.

Hierdie artikel ondersoek die wyse waarop Christelike gesindheid in sulke omstandighede kan funksioneer sodat die opsies van destruktiewe optrede, aggressie en geweld vermy kan word. Hierdie opsies moet vermy word omdat konfliknavorsing toon dat selfgeldende verset kan lei tot 'n spiraal van onbillike en onregverdige gesagstoepassing wat ordelike samelewings binne gesagskringe versteur en maklik kan lei tot anargie (Camara 1974:139). Die probleme wat reeds genoem is, word daarom beredeneer in die lig van die norme wat voortvloei uit 'n Christelike visie op Christelike gesindheid as die grondslag van Christelik-etiese handelinge. Die sentraal-teoretiese argument is dat die Christelike gesindheid van diensvaardigheid, offervaardigheid, diens en gehoorsaamheid aan God wat gebou is op die gesindheid van Christus, rigtinggewend is vir Christelik-etiese handelinge binne 'n onregverdige gesagsisteem. 'n Christen moet bereid wees om as dienskneg sover moontlik geweldloos op te tree en selfs onreg te lei ten gunste van die stabiliteit binne 'n gesagsisteem. As oplossing word voorgestel dat 'n Christen eerder moet soek na alternatiewe voorkomende weë om konflik te vermy ten einde die openbare orde te dien en vrede te bevorder. Sulke weë vir konflikvermyding behoort in 'n gesagsisteem ingebou te wees.

In die bespreking wat volg, word eerstens aandag gegee aan Christelik-etiese beginsels wat ter sprake is wanneer die plig van gesagsdraers en die verantwoordelikheid van onderdane ter sprake is. Daarna word etiese norme neergelê vir strategieë van verandering. Alhoewel gesagsverhoudinge oor veel meer gaan as gesag in die sfeer van die staat, word in die beredenering en die aanbieding van voorbeelde wat hierna volg, merendeels verwys na die funksionering van Christelike gesindheid binne die raamwerk van politieke protes in staatsverband. Dieselfde beginsels kan egter ook op ander samelewingsverbande toegepas word. Ten opsigte van strategieë van verandering in die politieke sfeer word aandag gegee aan die strategieë van gewapende verset, burgerlike ongehoorsaamheid en eksterne druk. 


\section{Christelike gesindheid en politieke protes}

\section{ETIESE BEGINSELS}

\subsection{Die verantwoordelikheid van 'n gesagsdraer}

In die Christelike etiek word aanvaar dat alle gesag van God af kom en dat $\mathrm{Hy}$ gesag ingestel het om orde moontlik te maak in 'n gebroke bedeling. Op grond van hierdie uitgangspunt kan die volgende beginsels afgelei word:

- Die koninkryk van God is die primêre gesagsfeer. Die uitdrukking "koninkryk van God" word nie in die Ou Testament gevind nie, hoewel die saak van God se koningskap oor alle dinge wel deeglik voorkom. In die Nuwe Testament kom die uitdrukking veral in die Evangelies voor as beskrywing van die domein, volk en lewe waaroor Christus regeer. Hy ontvang alle mag in die hemel en op aarde (Matt 28:18) (Bright 1968:188; Ridderbos 1969:18).

- Die kleinste gesagskring wat God gee, is die gesag in die kring van die huwelik en die gesin. God skep man en vrou, beskik die gesin en gee duidelike beginsels vir die funksie, doel en taak van die gesin en familie. Hierdie beginsels word in die Nuwe Testament bevestig en wel in ooreenstemming met die versoenende werk van Christus wat beskou word as die basis van 'n goeie huweliks- en gesinsverhouding.

- Onder die gesagsfere as skeppingsordeninge van God val ook die konsep van "volk van die Here". Die volk van die Here (of Godsvolk) word na die sondeval geroep as die volk van die verbond. Hierdie volk van die verbond is Israel wie se geskiedenis, heilshistories gesien, uitloop op die Nuwe-Testamentiese kerk (Coetzee 1965:150). Binne hierdie volk as 'n religieuse gemeenskap regeer God op 'n teokratiese wyse (Küng 1992:54). In die universele kerk wat manifesteer in elke plaaslike kerk word hierdie regeringswyse beliggaam in die regering van Christus deur die Woord en Gees.

- Die gesag wat God gee, kring verder uit tot die wye kring van staatsgesag (Douma 1996179). In die Ou Testament sluit die benaming "volk van die Here" sowel staatsgesag as geestelike regering in. Albei gesagsvorme funksioneer as 'n teokrasie waarbinne op verskeie maniere gevra kan word na die wil van die Here. In die NuweTestamentiese openbaring word kerk en staat geskei en elkeen ontvang 'n eiesoortige doel, funksie en terrein. God beskryf die taak van die owerheid net soos hy die taak van die kerk beskryf. Die 
owerheid is nie per se sekulêr, onheilig of - soos Openbaring se dier uit die aarde nie. Soos in die kerk moet die gesag wat God gee, ook in die staat manifesteer, want die swaardmag wat die staat hanteer, word ook deur Christus gegee en staan onder sy regering (Baer \& Caprizzi 2005:134).

- Hierdie instelling van gesagsfere sluit nie uit dat ander gesagsfere nie ook kan ontwikkel nie. Daar kan juis geredeneer word dat God se algemene goedheid die mens in staat stel om ander samelewingsverbande daar te stel ten einde orde te handhaaf en vrede en geregtigheid te bevorder. God het skole byvoorbeeld nie direk ingestel nie; tog het die mens in sy taak om die skepping te ontwikkel en te ontgin skole gestig om die opvoedingstaak uit te voer. Net so is universiteite daargestel om die wetenskap te beoefen.

Die sfere waarin gesag funksioneer, is die samelewingsverbande waarin mense leef. In die Reformatoriese filosofie het 'n pluralistiese samelewingsfilosofie ontwikkel waarin samelewingsverbande naas mekaar elk op sy eie wyse 'n eiesoortige soort gesag uitoefen (Stackhouse 1995:26). Binne hierdie filosofie word twee soorte samelewingsverbande onderskei, naamlik institutêre verbande en vrye assosiasies. Institutêre verbande is dié wat deur God self ingestel is: die huwelik, gesin, kerk en staat. Vrye assosiasies is samelewingsverbande wat histories ontwikkel het en sluit verbande in soos skole, politieke partye, vakunies, verenigings, klubs, ensovoorts (Van der Walt 1999:104). Elke samelewingsverband het 'n eie taak, gebied en werksterrein en besit soewereiniteit in eie kring. Ook het elkeen ' $n$ funderende en 'n kwalifiserende aspek. Elke samelewingsverband het 'n eie historiese ontwikkelingsgang deurloop en elkeen word gekwalifiseer deur 'n bepaalde eiesoortigheid. Die geïnstitueerde kerk word gekwalifiseer deur die bediening van die Woord en die sakramente, terwyl die staat geregtigheid in die samelewing moet vergestalt deur ordelike bestuur. Die vraag kan egter gestel word wat hierdie geregtigheid impliseer. Rawls (2001:392) se regsfilosofiese definisie van geregtigheid as billikheid kan in hierdie verband van toepassing gemaak word, hoewel hy geregtigheid uit 'n ander filosofiese vertrekpunt omskryf. Volgens Rawls tree die owerheid billik op wanneer dit verseker dat elke mens gelyke toegang tot basiese regte en vryhede het en wanneer ampte en posisies vir elkeen oop en toeganklik en tot voordeel vir die mins ontwikkeldes in die samelewing is. Hierdie beskrywing is waardevol wanneer geoordeel moet word of 'n staatsbestel regverdig of onregverdig is. 


\section{Christelike gesindheid en politieke protes}

Wanneer samelewingsverbande se soewereiniteit in eie kring geskend word, dit wil sê, wanneer die een oor die ander een heers deur die eie identiteit en gesag oor eie sake te verdring, lei dit tot totalitarisme. Tog is die verbande, met behoud van eie integriteit, ook op mekaar aangewys en funksioneer hulle aanvullend om sodoende die hele gemeenskap te dien (Stackhouse 1995:26). Wanneer hierdie harmonie versteur word, lei dit tot anargie.

In al hierdie verbande funksioneer bepaalde gesagsverhoudinge. Vir hierdie gesagsverhoudinge bied die Skrif beginsels vir ordelike gesagshantering en die aanvaarding daarvan. Die algemene beginsel is dat gesag gehoorsaam moet word en dat eer aan gesagsdraers bewys moet word. Van der Walt (1999:110) wys daarop dat gesag op twee maniere verkeerd hanteer kan word. Wanneer geredeneer word dat God gesag oordra aan gesagsdraers, lei dit tot 'n hiërargiese gesagsbeskouing waarin amptenare elitisties begin optree. Dan word 'n gesagsdraer gesien as 'n plaasvervanger van God. So 'n beskouing lei tot magsmisbruik. Wanneer geredeneer word dat alle gesag van onder kom, dit wil sê dat onderdane die gesag toeken deur 'n meerderheidstem, lei dit tot meerderheidstirannie. So 'n tirannie kom tot stand wanneer byvoorbeeld geredeneer word dat die "wil van die volk die wil van God is". Volgens Van der Walt - en in ooreenstemming met 'n Reformatoriese beskouing - ken God gesag aan 'n amp toe en die amp is altyd verantwoording aan God verskuldig vir die hantering van daardie gesag. Gesagsdraers word nie plaasvervangers van God nie, maar bly steeds diensknegte van God en hanteer ' $n$ amptelike gesag. Ampsdraers se gesag is gekwalifiseerde gesag wat bepaal word deur die kwalifiserende funksie van die samelewingsverband waarin hierdie gesag funksioneer.

\subsection{Die verantwoordelikheid van 'n onderdaan}

Die verantwoordelikheid van 'n onderdaan in 'n gesagsverhouding kan in die volgende stellings saamgevat word:

- Die grondslag van die verantwoordelikheid van 'n onderdaan word beskryf in die vyfde gebod (Heyns 1970:173). Hoewel die vyfde gebod handel oor die eer en gehoorsaamheid wat aan ouers bewys moet word, strek die betekenis van die handeling van eer en gehoorsaamheid ook wyer en omskryf dit die gehoorsaamheid wat onderdane aan gesagsdraers verskuldig is (Douma 1996:179). Die belofte wat in dié gebod uitgespreek word, verskaf die rede waarom daar gesag is en waarom dit gehoorsaam moet word. 'n Gesonde gesagsverhouding is nodig vir 'n vreedsame samelewing in die land wat God gee. 'n Onder- 
daan moet gesag antwoord met ontsag (Van der Walt 1999:110). 'n Onderdaan moet gesag derhalwe gehoorsaam omdat gesag van God af kom. Die gesindheid van 'n Christen as onderdaan in 'n gesagsverhouding is dus dié van wetsgehoorsaamheid. Hierdie wetsgehoorsaamheid word bepaal deur die kwalifiserende funksie van die samelewingsverband waarin die gesag funksioneer. 'n Staatkundige leier wat in die politieke sfeer 'n gesagvoerder is, kan byvoorbeeld in die kerklike sfeer 'n onderdaan wees. Op die een terrein het hy gesag, maar op die ander terrein ontsag. Sy gesag in die een sfeer kan nie oorgedra word op 'n ander terrein nie, omdat sodanige oordrag tot totalitarisme en dus magsmisbruik sal lei. Elke mens moet balans hanteer in die dra van gesag en die uitdrukking van ontsag. In albei gevalle is die mens primêr aan God verantwoording verskuldig. Jesus se onderwysing dat onderdane die keiser gehoorsaam moet wees en aan hom "moet gee wat hom toekom", dui ook daarop dat gesagsdraers en die wyse waarop hulle hulle gesag bekom het, nie op sigself gesien kan word as 'n rede om hulle gesag te verwerp nie.

- Ontsag vir gesagsdraers moet gepaardgaan met gebed vir hulle wat in gesagsposisies is. Hierdie opdrag in I Timoteus 2:1-2 word, soos die vyfde gebod, gekoppel aan orde in die samelewing. Die doel van 'n onderdaan se gebed vir gesagsdraers is daarop afgestem dat mense 'n "rustige en stil lewe kan lei in volkome toewyding aan God en in alle eerbaarheid". Ook in hierdie opsig word ontsag vir gesag by implikasie gekoppel aan die orde in die samelewing. Gehoorsaamheid aan gesag is dus ' $n$ baie belangrike beginsel vir die gesindheid van ' $n$ Christen binne die verskillende samelewingsverbande en 'n saak waarmee nie ligtelik omgegaan moet word nie.

- Die ontsag van onderdane en die gesag van gesagsdraers word egter ook begrens. Ontsag kan nie absoluut opgeëis word nie. In Handelinge 5:29 kry gelowiges die opdrag om aan God meer gehoorsaam te wees as aan mense en hierdie opdrag geld ook vir gesagsdraers. Wanneer die eise wat ampsdraers stel, in stryd is met wat God van 'n gelowige verwag, moet gehoorsaamheid aan God eerste gestel word. In die lig hiervan maak die Christelike etiek voorsiening vir geregverdigde ongehoorsaamheid. Oor wat die aard daarvan behoort te wees, sal later gehandel word. 


\section{Christelike gesindheid en politieke protes}

Die verantwoordelikheid van 'n onderdaan is om ontsag te hê vir gesag soos wat gesag in alle samelewingsverbande gekwalifiseer word. 'n Burger is ontsag verskuldig aan die staat, 'n lidmaat aan 'n ouderling, 'n werker aan 'n werkgewer, 'n kind aan 'n ouer, 'n lid van 'n vereniging of klub aan die bestuur van daardie vereniging en 'n leerder aan 'n leermeester. Gesagsdraers moet ook deur die gebede van onderdane gedra word, want sodoende verseker God orde en vrede. Hierdie ontsag het egter ook perke. Wanneer gesag die gehoorsaamheid aan God bedreig, bewys sodanige gesag sigself ongeldig en dan moet 'n onderdaan hom- of haarself onderwerp aan die hoogste gesag, naamlik aan God. In sulke gevalle het onderdane die reg voor God om strategieë van verset uit te werk. Maar ook in hierdie strategieë geld Christelike gesindheid en etiese norme wat die koers, metode, doel en gesindheid van die opstandeling en die aard van die verset moet omlyn.

\section{STRATEGIEË VAN VERSET}

Verskeie strategieë van verset teen onregverdige gesagsisteme, veral teen die staat, het in die onlangse verlede in verskeie wêrelddele gefunksioneer ten einde sosiale verandering te weeg te bring. In hierdie opsig kan gewys word op die klassieke teorie van gewapende verset, lydelike verset of burgerlike ongehoorsaamheid en eksterne druk. Elkeen van hierdie opsies word vervolgens eties beoordeel ten einde te kom by 'n strategie wat pas by die beginsels van Christelike gesindheid en die dienskneggestalte wat 'n Christen behoort te hê.

\subsection{Gewapende verset}

Gewapende verset het in die geskiedenis op verskeie wyses voorgekom en is gedra deur verskillende sosiale analises. In die laaste drie dekades van die einde van die vorige eeu het die filosofie van rewolusie hierdie strategie weer met 'n nuwe ontleding van samelewingsproblematiek aan die orde gestel (die term sosiale analise is die tegniese term wat in die etiek hiervoor gebruik word). Die belangrikste eksponent van hierdie filosofie was Marcuse wat veral gesteun het op die psigologie van Freud. ${ }^{2}$ Volgens Marcuse lê die groot probleem van die hedendaagse samelewing daarin dat dit 'n gemeenskap is wat die vryheid van die individu inperk. 'n Individu is nie vry om homself

\footnotetext{
${ }^{2}$ Dié beskouing van Marcuse het die grondslag gevorm van die sosiale analise (ontleding van die sosiale problematiek) en strategie van verset van die Neo-Marxisme. Verskeie versetstryde, waaronder dié in Suid-Afrka en in Latyns-Amerika is volgens hierdie patroon gevoer. Die New Left-beweging het in die sewentigerjare van die vorige eeu in Europa en die Verre Ooste groot politieke veranderinge volgens hierdie patroon tot stand laat kom. Vir 'n breedvoerige uiteensetting van die filosofiese agtergrond, grondlyne en impak van hierdie filosofie kyk Vorster (1981a:221). 'n Korter populêr-wetenskaplike oorsig word gevind in Vorster (1981b:7)
} 
volledig uit te leef nie; 'n individu is slaaf van 'n ekonomiese en politieke sisteem wat sy hele lewe beheer. Hy leef nie meer nie, hy word geleef. 'n Individu is net ' $n$ ratjie in ' $n$ groot samelewingsmasjien en al sy ideale en talente is onderworpe.aan die belange van die groot geheel ' $n$ Individu is 'n slaaf van groot gesagstrukture. Hierdie slawerny kan polities, ekonomies, maatskaplik en godsdienstig van aard wees en kom na vore in sosio-politieke strukture, hedendaagse ekonomiese stelsels, opvoedkundige inrigtings en ander samelewingsverbande - selfs in die gesin. Op al hierdie gebiede is dit, volgens Marcuse, die individu en sy ideale wat opgeoffer moet word vir "magstrukture" en hulle belange.

Op grond hiervan sê Marcuse dan dat solank hierdie onderdrukkende strukture bestaan, sal die mens altyd onvry, 'n slaaf van die sisteem, of, soos hy dit noem, " $n$ eendimensionele mens" wees. Om waarlik vry te wees moet hierdie juk afgegooi word en dit kan alleen geskied in 'n sisteem wat aan voortdurende verandering onderhewig is. Vir die inwerkingstelling van sodanige veranderende struktuur het Marcuse 'n strategie ontwerp waarin hy die idee van rewolusie, soos verwoord deur Marx, ingebou het. Dié strategie is gemik op die bevryding van die individu deur die rewolusionêre omverwerping van die bestaande orde. Omdat die sisteem inherent gewelddadig is, mag teengeweld daarteen aangewend word in die vorm van gewelddadige verset. ${ }^{3}$ Cone (1975:219) het Marcuse se strategie treffend verwoord met die stelling dat "no one can be nonviolent in an unjust society". Die struktuur moet in sy geheel "teengeleef" word en die kanale van protes, soos byvoorbeeld stemreg, moet verwerp word. Om die strukture se proteskanale te gebruik word beskou as samewerking met die sisteem. Op hierdie manier het Marcuse se filosofie van rewolusie gewelddadige verset tot so 'n mate geromantiseer dat selfs kerke dié opsie gelegitimeer het. ${ }^{4}$ Die geldelike steun wat kerke aan bevrydingsbewegings se gewapende verset in Suid-Afrika en Latyns-Amerika gegee het, getuig van die invloed wat hierdie filosofie gehad het.

Die filosofie van rewolusie se vrugte, naamlik die strategie van gewapende verset en wetteloosheid kan beoordeel word aan die hand van die Suid-Afrikaanse ervaring gedurende die laaste twee dekades van die vorige

\footnotetext{
${ }^{3}$ Marcuse se sosiale analise (ontleding van die sosiale problematiek) en pleidooi vir rewolusie word uiteengesit in Marcuse (1964:10; 1968:7, 149 en 155; 1969; 1970:86; 87); Marcuse \& Popper (1971a:17-19) en Marcuse (1971:273).

4 'n Goeie uiteensetting van dié siening hieroor word gevind in die bundel Theology and violence. The South African debate (Villa-Vicencio 1988) wat in die konteks van die gewapende stryd teen apartheid in Suid-Afrika gepubliseer is onder redakteurskap van VillaVicencio. Prominente Suid-Afrikaanse teoloë hanteer die opsie van gewapende verset vanuit hulle onderskeie kerklike tradisies en kom oor die algemeen tot die konklusie dat gewapende verset onder bepaalde omstandighede geregverdig kan word.
} 


\section{Christelike gesindheid en politieke protes}

eeu. Die eerste vraag wat in hierdie verband gevra kan word, is in hoeverre die strategie van gewapende verset versoen kan word met die liefdesgebod? Moet 'n Christen nie eerder bereid wees om onreg te lei nie? Is pasifisme nie meer versoenbaar met die gesindheid van Christus nie? Die Christelike tradisie sedert Augustinus het 'n saak uitgemaak vir geregverdige oorlogvoering. Oorlog is gesien as geregverdig as dit gevoer word deur ' $n$ wettige owerheid, as dit gaan om 'n regverdige saak, as die bedoeling edel is en as dit die laaste opsie is (Baer \& Caprizzi 2005:121). Met die uitsondering van die eerste voorwaarde word dieselfde voorwaardes vir gewapende verset gestel. Die konklusie is dan dat gewapende verset vir 'n Christen aanvaarbaar kan wees wanneer al die ander weë van geweldlose verset nie verandering teweegbring nie.

In die Christelike etiek kan die legitimiteit van gewapende verset (of rewolusie) benader word vanuit 'n deontologiese en vanuit 'n konsekwensialistiese teorie. Vanuit die deontologiese teorie maak Geisler (1991:250), myns insiens, 'n geldige saak uit teen die opsie van gewapende verset. Geisler se argumente om sy siening te begrond sluit die volgende in:

- God het aan die owerheid die swaardmag gegee om te regeer; God het nie aan die onderdaan die mag gegee om te rebelleer nie (Gen 6:11; 9:6; Rom 13:4).

- God verbied saamspan met rebellerendes (Spr 24:21).

- Rewolusies word deurgaans deur God veroordeel (Num 1 6:2 Sam 15; 1 Kon. 12).

- Moses is veroordeel vir sy geweldadige daad in Egipte (Eks 2:12).

- Israel het nie teen die Farao geveg nie, maar eerder gevlug (Eks 12).

- Jesus het gepreek teen die gebruik van geweld (Matt 26:51-52).

- Jesus het ook gepreek teen wraak (Matt 5:38-39).

Volgens Geisler (1991:251) behoort 'n Christen in plaas van gewapende verset die wette van die owerheid te gehoorsaam. Hy grond hierdie standpunt op Romeine 13:1; Titus 3:1 en 1 Petrus 2:13, hoewel hy ook voorsiening maak vir burgerlike ongehoorsaamheid. (Op hierdie aspek word weer later teruggekom.) 'n Christen moet ook vir die owerheid bid en verandering bevorder deur die voorbeeld van 'n deugsame lewe. 'n Christen moet vreedsaam en wettig werk vir verandering, eerder vlug as rebelleer en onreg geduldig verduur.

In aansluiting by dié standpunt van Geisler kan ook uit die oogpunt van 'n konsekwensialistiese teorie gevra word of die tradisionele Christelik-etiese teorie van 'n uis ad bellum nog houdbaar is. Die rede waarom hierdie vraag gestel behoort te word is tweërlei. 
Eerstens is dit ' $n$ feit dat politieke konflik nie meer beperk is tot streke in die huidige globaliserende wêreld nie. Konflik word maklik geïnternasionaliseer. Konflik op streeksvlak betrek magte van buite omdat globalisering ekonomiese belange ver buite die grense van politieke entiteite vestig. Die konflik tussen Israel en die Palestyne byvoorbeeld, skep konflik ver buite die grense van daardie streek. Opstand van minderhede in die Arabiese lande beïnvloed ekonomiese verkeer in die VSA en Europa en betrek daardie regerings onvermydelik by die stryd. In Afrika het die etniese stryde in Sentraal-Afrika implikasies vir Suid-Afrika omdat duisende vlugtelinge hier 'n heenkome soek. Geweld op streeksvlak ontwikkel dus maklik tot geweld op 'n wyer vlak.

Tweedens is wapens van massavernietiging vandag wyd beskikbaar. Gewapende versetbewegings kan wapentuig bekom wat vernietigende gevolge het. Dit blyk dus dat dit vandag onmoontlik geword het om die opsie van gewapende verset op 'n gekontroleerde en doelgerigte wyse uit te voer. Rebellerendes het nie beheer oor die uitkoms (konsekwensies) van hulle rebellie nie. Hierdie nuwe realiteite noop die Christelike etiek om weer oor die opsie van geweld as strategie van verandering te besin. In hierdie besinning kan die gewapende versetstryd wat in Suid-Afrika gevoer is, terugskouend beoordeel word as ' $n$ voorbeeld hiervan. Op grond van so ' $n$ beoordeling word die volgende probleme, wat uit hierdie opsie voortgevloei het, duidelik:

- Eerstens kan gevra word: het die gewapende stryd in Suid-Afrika die proses van verandering bespoedig of vertraag? Die stryd het ongeveer vyftien jaar geduur en het algaande geëskaleer en meer en meer partye op internasionale vlak betrek. Voorts is geen grondgebied in die Republiek van Suid-Afrika deur die versetbewegings beset nie. Geeneen van die partye het die ander tot oorgawe gedwing nie. Elkeen het geëis dat strukturele geweld en teengeweld gestaak moet word en juis hierdie voorwaardes het onderhandelinge ondermyn. Die konklusie kan dus gemaak word dat gewapende verset die veranderingsproses in Suid-Afrika eerder vertraag as bespoedig het - met gepaardgaande groot koste en lewensverlies.

- Die gewapende verset teen die onregverdige staatstruktuur van daardie tyd het ' $n$ spiraal van geweld en uitgerekte oorlog veroorsaak. Die gemeenskap in Suid-Afrika het enorme geestelike, morele en ekonomiese skade gelei. Ekonomiese beplanning het al hoe meer om verdediging gewentel en belangrike besteding aan byvoorbeeld 


\section{Christelike gesindheid en politieke protes}

behuising, onderwys, gesondheids- en maatskaplike dienste het daaronder gelei.

- Soos in enige oorlog en geweldpleging het die morele peil van die gemeenskap gedaal. Die verslag van die Suid-Afrikaanse Waarheidsen Versoeningskommissie het gewys op onmenslike wandade wat deur albei partye in die stryd gepleeg is (Truth and Reconciliation Commission 1998). Mense is vermoor, ontmenslik, ontwrig en getraumatiseer tot so 'n mate dat die samelewing dekades gaan neem om van die geestelike en morele skade te herstel.

- Die gewapende stryd en die wandade wat daarmee gepaardgegaan, het het groot bitterheid, verdeeldheid en intense rassespanning in SuidAfrika tot gevolg gehad. Die stryd was gekenmerk deur 'n wit gemeenskap teen 'n swart gemeenskap met "kerk" aan albei kante. Christene was aktief aan albei kante van die stryd. Kapelane het in albei partye het die motivering vir die oorlogspoging op Bybelse gronde verskaf. Die stryd het so diep gesny dat versoening 'n lang proses gaan wees.

- Die stryd het 'n gemeenskap nagelaat waarin misdaad gefloreer en respek vir lewe en eiendom 'n laagtepunt bereik het. Die beskikbaarheid van wapens, die oortuiging dat die samelewing aan mense iets skuld vir die stryd wat gevoer is, naakte rassisme, disrespek vir wette en polisiëring het wettelose optrede nie net meer moontlik gemaak nie, maar selfs moreel geregverdig in die oë van die voormalige stryders.

Hierdie negatiewe gevolge van die gewapende stryd in Suid-Afrika verskerp die argument dat die teorie van "geregverdige oorlog" nie meer houdbaar is nie: die uitkoms is merendeels immoreel. Wanneer ' $n$ betreklik laeintensiteitoorlog soveel negatiewe gevolge het, hoeveel te meer sal dit nie die geval wees met ' $n$ volskaalse hoë-intensiteitoorlog met vernietigende wapentuig nie? Hoewel die opsie van geregverdigde verset deur die Christelike etiek in die verlede aanvaar is, moet onderdane hierdie opsie liefs vermy in die lig van Skriftuurlike beginsels en die kontekstuele toepassing van etiese norme in 'n tyd waarin konflik maklik geïnternasionaliseer word en wapens van massavernietiging beskikbaar is. Vanweë prinsipiële besware en die waarskynlik negatiewe uitkomste van sodanige verset in ons tyd kan hierdie strategie van verandering moeilik versoen word met die kernidees van Christelike 
gesindheid. Dit is daarom nodig om verder te besin oor ander strategieë van verandering.

\subsection{Burgerlike ongehoorsaamheid}

Burgerlike ongehoorsaamheid moet duidelik onderskei word van gewelddadige verset en volskaalse rewolusie. Waar gewelddadige verset daarop gerig is om die bestaande owerheid met geweld omver te gooi en rewolusie die totale afbreek van 'n sisteem in die oog het, wil burgerlike ongehoorsaamheid bepaalde wette wat as diskriminerend en verontregtend ervaar word, doelbewus verontagsaam ten einde die owerheid te oortuig dat verandering nodig is. Die regsfilosoof Rawls (2001:181) verstaan onder burgerlike ongehoorsaamheid die volgende: "A public, nonviolent and conscientious act contrary to law usually done with the intent to bring about a change in the politics or laws of the government."

Hy sê verder dat burgerlike ongehoorsaamheid daarop gerig moet wees om die sin vir geregtigheid vir die meerderheid na vore te bring. As sodanig moet burgerlike ongehoorsaamheid gesien word as ' $n$ uitingsvorm en 'n uitdrukking van oortuiging. Burgerlike ongehoorsaamheid moet dus openbare en nie-geweldadige optrede impliseer en sodanige optrede moet uitgevoer word in 'n situasie waar arres en straf verwag en sonder verset aanvaar word.

Burgerlike ongehoorsaamheid binne ' $n$ duidelik onregverdige sisteem is 'n voor die handliggende opsie. 'n Bekende vorm hiervan was die verset van Ghandi teen die Britse koloniale regering in Indië gedurende die eerste helfte van die vorige eeu. Hy was sterk gekant teen enige vorm van geweld en het sy protesoptrede gedefinieer as lydelike verset. Hierdie verset het wegblyaksies en die ignorering van onderdrukkende wette en maatreëls ingehou. Hy het die hele Indiese gemeenskap by hierdie optrede probeer betrek. Met enkele uitsonderings het sy protes geweldloos verloop en was dit op die lange duur suksesvol.

Gedurende die vryheidstryde wat na die Tweede Wêreldoorlog in Afrika en Latyns-Amerika ontwikkel het, is hierdie vorm van burgerlike ongehoorsaamheid toegepas en dit het 'n aktuele tema in die Christelike etiek geword. In die tyd van verset teen die stelsel van apartheid was burgerlike ongehoorsaamheid ' $n$ belangrike strategie en is daar in feitlik alle teologiese tradisies oor hierdie saak besin. Etici het in 'n groot mate konsensus gehad oor die aanvaarbaarheid van dié strategie om sodoende 'n einde te bring aan die stelsel van apartheid. Die saak het intussen egter meer gekompliseerd geword. Dit het nou duidelik geword dat binne 'n sisteem soos byvoorbeeld ' $n$ grondwetlike demokrasie, wat op die oog af 'n regverdige politieke sisteem 


\section{Christelike gesindheid en politieke protes}

blyk te wees, mense hulle ook tot hierdie strategie wil wend om te protesteer teen diskriminerinde praktyke, maatreëls en beleidsrigtings. Enkele voorbeelde kan genoem word:

- As gevolg van globalisering word lande meer en meer heterogeen. Etniese minderhede het ontwikkel in lande wat vir eeue homogeen was. Hierdie minderhede voel hulle bedreig in gemeenskappe wat vir eeue hulle etos met allerlei maatreëls gehandhaaf het. ' $n$ Minderheid met 'n eie etos kan hom bedreig voel binne so 'n heterogene samelewing met ' $n$ eie gevestigde tradisie. Ten einde minderheidsregte te bekom gebruik minderheidsgroepe dan die strategie van burgerlike ongehoorsaamheid. Hoewel hulle politieke en burgerlike regte geniet, bied die uitoefening van hierdie regte, soos stemreg, nie resultate nie vanweë die betrokke minderheidsgroep se onvermoë om die meerderheid polities te beïnvloed. ' $n$ Goeie voorbeeld hiervan is die situasie van Afrikaners in Suid-Afrika. Al het hulle stemreg, kan hulle die politieke beleid nie wesenlik beïnvloed nie, omdat hulle 'n minderheid is. Sulke minderhede kan dan burgerlike ongehoorsaamheid as 'n opsie kies om daardie maatreëls wat hulle etos bedreig, nie te gehoorsaam nie. Afrikaners kan, byvoorbeeld, besluit om nie lisensiegeld vir die gebruik van televisie te betaal nie, omdat hulle oordeel dat hulle taal op die nasionale televisienetwerke bedreig word of hulle kan besluit om eiendomsbelasting terug te hou omdat Afrikaanse plek- en straatname verander word om die geskiedenis van slegs die meerderheid uit te beeld. Hierdie is eenvoudige voorbeelde, maar ander ernstiger situasies kan ontwikkel waarin na dieselfde strategie gegryp kan word.

- Burgerlike ongehoorsaamheid is ook tans aktueel in die mediese etiek (Macauley 2005:38). 'n Sekulêre grondwet met ' $n$ humanistiese morele basis kan mediese praktyke aan gesondheidswerkers opdwing wat gewetens-besware by hulle ontlok en hulle dwing om doelbewus onwettig op te tree. 'n Voorbeeld hiervan is staatshospitale se praktyk om babas wat te vroeg gebore word, van mediese behandeling te weerhou terwyl gespesialiseerde behandeling wel hulle lewens kan red. Gesondheidswerkers verbreek dan doelbewus die regulasies deur - in stryd met die beleid - behandeling aan die babas te gee ten einde hulle lewe te probeer red. 
- 'n Ander voorbeeld van burgerlike ongehoorsaamheid in die mediese etiek is die verbod op die bekendmaking van die status van MIV/Vigspasiënte. Hoewel medici nie inligting oor die status van 'n MIV/Vigspasiënt aan ander mag verskaf nie, kan 'n medikus die opsie kies om byvoorbeeld iemand wat as MIV-positief gediagnoseer is se status bekend te maak aan die naby familie van so 'n persoon ten einde die moontlike verspreiding van die siekte in daardie kring te verhoed. So 'n optrede is in stryd met die kode wat vir medici in hierdie opsig geld. Tog vind gesondheidswerkers regverdiging vir hulle optrede op grond van die legitieme strategie van burgerlike ongehoorsaamheid.

- Op die internasionale front bestaan daar ook verskeie situasies waar gemeenskappe hierdie strategie hanteer ten einde hulle saak te bevorder. In hierdie opsig kan gewys word op die Palestyne in hulle verset teen die regering van Israel, die Irakese teen die Amerikaansgesteunde nuwe Irakese regering, die lere teen die Britte in Noord-lerland en talryke minderheids-groepe wêreldwyd wat die strategie van burgerlike ongehoorsaamheid toepas teen hulle regerings wat uit etniese meerderheidsgroepe bestaan. Die voorbeelde is legio.

Wat is die norme vir burgerlike ongehoorsaamheid in 'n grondwetlike demokrasie soos die hedendaagse Suid-Afrika? Beteken die feit dat die regering 'n demokraties verkose meerderheidsregering onder toesig van 'n grondwetlike hof is dat burgerlike ongehoorsaamheid nie 'n strategie van verandering mag wees nie? Rawls (2001:176) erken die reg van burgerlike ongehoorsaamheid selfs in 'n grondwetlike demokrasie. Hiervoor beroep hy hom op die idee van die staat as 'n sosiale kontrak soos, onder andere, uitgewerk deur Locke. Locke (1988:271) het gesê die staat word gevorm as gevolg van 'n kontrak deur die burgery wat tot stand kom deur die uitoefening van kiesreg. Die burgery kom ooreen oor die bepalings van die kontrak deur te vereis dat bepaalde basiese regte beskerm moet word. Wanneer die staat hierdie regte nie laat realiseer nie, verval die kontrak en moet 'n nuwe kontrak deur middel van verkiesings daargestel word. ${ }^{5}$ Rawls (2001:177) meen dat wanneer die owerheid onregverdig optree, dit die sosiale kontrak verbreek. In sodanige geval kan die owerheid nie meer aanspraak maak op die ontsag van sy onderdane nie.

\footnotetext{
5 ' $n$ Insiggewende artikel oor die godsdiens, lewe en agtergrond van Locke is geskryf deur Pearson (1978:244-262) en dien as 'n goeie agtergrond om Locke se politieke filosofie te verstaan.
} 


\section{Christelike gesindheid en politieke protes}

Wanneer kan verklaar word dat die staat onregverdig optree? In aansluiting by sy siening van geregtigheid as billikheid sê Rawls (2001:178) dat die staat onregverdig optree as al die burgers nie dieselfde vryhede geniet nie en as ampte en posisies nie vir almal in gelyke mate toeganklik is nie. Elkeen moet dus dieselfde vryhede geniet en elkeen moet die reg hê om in enige amp of posisie verkies te word. Indien een van hierdie twee voorwaardes verbreek word, het onderdane die reg van burgerlike ongehoorsaamheid.

Om die reg van burgerlike ongehoorsaamheid uit te oefen moet egter ook aan sekere voorwaardes voldoen word:

- Dit moet duidelik wees dat die normale weë van protes reeds gevolg is om die meerderheid te oortuig van die onregverdigheid van die staat se handeling en dat die beswaar ondanks hierdie protes verwerp is.

- Burgerlike ongehoorsaamheid moet ' $n$ politieke handeling impliseer wat daarop gerig is om die sin van regverdigheid vir die meerderheid na vore te laat kom. Verontregtings wat plaasgevind het, moet ook duidelik omlyn word

- Die reg van burgerlike gehoorsaamheid moet beperk word tot daardie gevalle waar die beswaarde gewillig is om te aanvaar dat almal wat aan dieselfde onreg blootgestel is, dieselfde weg kan volg, en

- dit waarskynlik is dat die optrede die gewenste uitwerking sal hê.

- Ook wanneer hierdie strategie van verandering Christelik-eties beoordeel word, kan burgerlike ongehoorsaamheid onder bepaalde voorwaardes as moreel geregverdig beskou word. Uitgaande van die beginsel dat 'n mens aan God meer gehoorsaam moet wees as aan mense, kan geoordeel word dat burgerlike ongehoorsaamheid geregverdig is wanneer die owerheid 'n wet maak wat strydig is met die Woord van God. Geisler (1991:241) noem hierdie standpuntinname die antipromulgation position. Self kies hy 'n meer genuanseerde posisie wat hy tipeer as anticompulsion position.

- Ten opsigte van die eerste posisie (die antipromulgation position) is burgerlike ongehoorsaamheid geregverdig as die owerheid verkeerde wette maak (wette in stryd met Skriftuurlike beginsels). 
- Ten opsigte van die tweede posisie (die antipromulgation position) is burgerlike ongehoorsaamheid geregverdig as die owerheid die onderdaan dwing om kwaad te doen.

In die mediese etiek kan die volgende voorbeeld genoem word om die onderskeiding te illustreer. Die feit dat die Suid-Afrikaanse owerheid aborsies op aanvraag toelaat, is nie ' $n$ rede dat gesondheidspersoneel hulle kan wend tot die opsie van burgerlike ongehoorsaamheid nie. Wanneer die owerheid hierdie personeel egter dwing om aborsies uit te voer kan die reg van weiering toegepas word. Eersgenoemde posisie kan maklik lei tot anargie, veral as die owerheid homself definieer as 'n neutrale of sekulêre owerheid soos in SuidAfrika die geval is. Laasgenoemde strategie skyn meer moreel te wees en kan verder ondersoek word.

Geisler (1991:244) gee die volgende belangrike Skriftuurlike gegewens om laasgenoemde opsie, naamlik weiering, te regverdig:

- In Eksodus 1:15-21 word verhaal hoe Sifra en Puah geweier het om die bevel van Farao uit te voer om die seuntjies van die Jode dood te maak. Hulle is vir hierdie daad deur die Here beloon.

- In Eksodus 5:1 word beskryf hoe Israel teen die bevel van Farao die Here gedien het. Die Here het hulle bevry.

- I Konings 18:4 handel oor Obadja se weiering om die profete op bevel van Isebel te dood. God het hierdie daad goedgekeur.

- Daniël het geweier om die afgod wat deur Nebukadneser opgerig is te aanbid (Dan 3). Die Here het hulle bewaar.

- Handelinge 4:18 toon hoe die apostels die evangelie verkondig het in stryd met die bevel van die Joodse Raad. Vir hierdie optrede het die mense God geprys.

- Uiteindelik sal gelowiges ook weier om die antichris te aanbid (Op 13:14); daarom sal hulle die lewe as kroon ontvang.

Burgerlike ongehoorsaamheid is dus nie net vir 'n gelowige ' $n$ aanvaarbare strategie om verandering te bewerkstellig nie, maar selfs 'n reg wanneer gesagsinstansies gelowiges dwing om hulle tot die kwade te wend. Dié strategie moet egter uitgevoer word binne die raamwerk van die norme wat 


\section{Christelike gesindheid en politieke protes}

Rawls as regsfilosoof en Geisler as etikus stel. Die belangrikste aspek hiervan is dat die optrede niegeweldadig en gekontroleerd moet plaasvind.

\subsection{Eksterne druk}

Die monstering van eksterne druk om 'n onregverdige gesagsisteem te verander word ook teenswoordig beskou as 'n belangrike strategie om verandering te bewerkstellig. Die bekendste voorbeeld van sodanige optrede is ekonomiese sanksies wat lande en finansiële instellings teen 'n onregverdige politieke gesagstruktuur kan toepas. Ekonomiese sanksies is suksesvol teen die apartheidregering in Suid-Afrika toegepas, terwyl dit tans teen verskeie onderdrukkende regerings in die wêreld toegepas word. Die beginsel ten grondslag van hierdie strategie is dat die onttrekking van steun, beleggings en handel, asook die opskorting van opvoedkundige en tegnologiese hulp die aandag vestig op die ongeregtigheid van 'n onregverdige sisteem. Ook word 'n gemeenskap deur middel van gewetensbeïnvloeding oorreed om wysigings aan te bring. Gewoonlik gaan dié strategie gepaard met wye publisiteit.

Vanuit 'n Christelik-etiese perspektief kan drie voorwaardes gestel word vir die toepassing van hierdie strategie.

- Eerstens moet die toepassing van hierdie opsie nie lei tot geweld nie, want dan ontaard dit maklik in gewapende verset met al die negatiewe gevolge wat reeds aangetoon is. Die grens tussen ekonomiese druk en die uitbreek van geweld in 'n sisteem is inderdaad baie fyn.

- Tweedens moet die strategie nie die verarming van 'n gemeenskap tot gevolg hê nie, maar moet dit gerig wees op gewetensbeïnvloeding en morele oorreding. Wanneer 'n gemeenskap verarm, lei dit uiteindelik onvermydelik tot geweld en anargie.

- Derdens kan die toepassing van eksterne druk slegs suksesvol wees as daar wye samewerking tussen eksterne rolspelers bestaan.

Die korporatiewe wêreld speel ' $\mathrm{n}$ al groter rol in hierdie strategie. Sowel Stackhouse (1995:43) as Berger (1995:88) wys op die belangrike rol wat globale mega-korporasies in die opbou van moraliteit speel en kan speel. Politieke mag word al minder en die mag van hierdie korporasies al hoe meer. Groot korporasies begin eie morele kodes opstel vir die posisionering en optrede op die internasionale ekonomiese en politieke toneel (United Nations' Non-Governmental Liaison Service 2002:14). Vandag kan hierdie groot 
finansiële instellings en korporasies weier om te belê en mee te doen aan lande en sisteme met swak menseregterekords. As die Menseregtekomissie van die Verenigde Nasies 'n negatiewe rapport opstel oor 'n staat se menseregterekord word dit 'n gerieflike dokument in die hande van megakorporasies om op die handhawing van basiese menseregte aan te dring deur gebruik te maak van die strategieë van weerhouding en onttrekking van investering (United Nations 2003:33). Hoewel hierdie optrede nie altyd vanweë morele redes in werking gestel word nie, maar eerder op grond van finansiële voordeel geïmplementeer word, word dit 'n belangrike instrument om onregverdige gesagsisteme doeltreffend te verander. Geen sisteem kan op die lange duur standhou as daar nie volgehoue investering is nie. Minderheidsgroepe wat benadeel word, werkers wat uitgebuit word en gemeenskappe wat ly onder die korrupsie van leiers, gaan hierdie strategie om verandering te bewerkstellig in die toekoms toenemend volg.

\section{KONKLUSIE}

Christelike gesindheid hef nie die reg op om gebruik te maak van die opsie van politieke protes en die volg van strategieë van verandering om onregverdige gesagsisteme te wysig nie. Christelike gesindheid word enersyds uitgedruk in die diensknegsgestalte van 'n Christen. Gesindheid word egter ook uitgedruk deur die feit dat 'n Christen aan God meer gehoorsaam moet wees as aan mense. Wanneer 'n gesagsisteem ' $n$ Christen direk of indirek dwing om kwaad te doen of om onreg te pleeg, kan teen sodanige sisteem opgetree word. Sekere voorwaardes geld egter indien teen sodanige sisteem opgetree word:

- Alle ander weë van protes moet uitgeput wees.

- 'n Spiraal van geweld moet vermy word.

- Die optrede moet nie anargie tot gevolg hê nie;

- Die strategie moet nie groter onreg ontketen nie.

- Die realistiese uitkoms van 'n verbeterde sisteem moet bestaan.

$\mathrm{Na}$ die eerste demokratiese verkiesing in Suid-Afrika het Villa-Vicencio (1994:98) die vraag gevra of Suid-Afrikaanse Christene en hul benaderingswyse nog bruikbaar is ten opsigte van sosio-politieke ontwikkelinge. Self gee hy bepaalde interessante en waardevolle antwoorde wat tot nadenke stem. Sy standpunte kom in breë trekke daarop neer dat die kerk intens betrokke moet wees by nasiebou. In samehang met dit wat hy sê, kan die volgende gedagte bygevoeg word: Christene behoort in die eerste plek nie net protesterend te wees nie, maar behoort proaktief op te tree. Positiewe roepingsvervulling 


\section{Christelike gesindheid en politieke protes}

beteken eerstens om voorkomend op te tree. As diensknegte van God en in ooreenstemming met die gesindheid van Christus moet Christene sosiaal betrokke wees en dit as 'n roeping sien om altyd te werk vir die vorming en opbou van eerbare gesagsisteme. Waar 'n Christen 'n gesagsdraer is, moet hy of sy die gesag wat God aan hom of haar toegeken het, sodanig hanteer dat God daardeur geëer word en die heil van die naaste daardeur gedien word. Christene moet hulle beywer vir gesagsisteme waarin die regte en effektiewe kanale van verandering ingebou is. As onderdane moet hulle deur voorbeeld en getuienis alle weë benut om 'n samelewing te skep waarin mense "'n rustige en stil lewe kan lei in volkome toewyding aan God en in alle eerbaarheid" (1 Tim 2:2).

\section{Literatuurverwysings}

Baer, H D \& Caprizzi J E 2005. Just war theories reconsidered: Problems with prima facie duties and the need for a political ethic. Journal of Religious Ethics 33(1), 119-137.

Berger $P$ L 1995. Vice and virtue in economic life, in Stackhouse, $M L$ (et al), Christian social ethics in a global era, 11-74. Nashville, TN: Abingdon.

Bright, J 1968. The Kingdom of God: The biblical concept and its meaning for the church. New York: Abingdon.

Camara, H 1974. Violence, the only way, in Kee, A (ed), A reader in political theology, 139-150. London: SCM.

Coetzee, J C 1965. Volk en Godsvolk in die Nuwe Testament. Potchefstroom: Pro Rege.

Cone, J H 1975. God of the oppressed. New York: Seabury.

Douma, J 1996. The Ten Commandments: Manual for Christian life. Phillipsburg: P \& R Publishing.

Fierro, A 1977. The militant gospel: An analysis of contemporary political theologies. London: SCM.

Geisler, N L 1991. Christian ethics: Options and issues. Grand Rapids, MI: Baker.

Gutierrez, G 1973. A theology of liberation. London: SCM.

Hauerwas, S 1981. A community of character. London: Notre Dame.

Heyns, J A 1970. Die nuwe mens onderweg. Kaapstad: Tafelberg.

Küng, H 1992. The church. Kent: Burns \& Oates.

Locke, J.1988. Two treatises of government. Cambridge: Cambridge University Press.

Macauley, R 2005. The Hippocratic underground, civil disobedience and the health care reform. Hastings Center Report 35(1), 38-45.

Marcuse, H 1964. One-dimensional man: Studies in the ideology of the advanced industrial society. Boston: Beacon Press.

Marcuse, $\mathrm{H}$ 1968. Eros and civilization. Boston: Beacon Press.

Marcuse, $\mathrm{H}$ 1969. An essay on liberation. Boston: Beacon Press.

Marcuse, $H$ 1970. Liberation from the affluent society, in Hamalian, $L$ \& Frederick, $K$ $\mathrm{R}$, The radical vision, essays for the seventies, 81-134. New York: City College of New York. 
Marcuse, $\mathrm{H}$ 1971. Re-examining the concept of revolution, in Lothstein, A All we are saying, the philosophy of the New Left, 273-283. New York: Apricorn Books.

Marcuse, H \& Popper K 1971. Sociale revolutie of sociale hervorming?: Een confrontatie. Baarn: Wereldvenster.

Pearson, S C 1978. The religion of John Locke and the character of his thought. Hastings Center Report 58, 244-262.

Rawls, J 2001. Collected papers. London: Harvard University Press.

Republiek van Suid-Afrika 1996. Die Grondwet van die Republiek van Suid-Afrika, 1996. Wet 108 van 1996. Pretoria: Staatsdrukker.

Ridderbos, H 1969. The coming of the kingdom. Philadelphia, PA: Presbyterian \& Reformed Publishing Company.

RSA kyk Republiek van Suid-Afrika

Stackhouse, M L 1995. Christian social ethics in a global era: Reforming Protestant views, in Stackhouse, M J (et al), Christian social ethics in a global era, 1174. Nashville, TN: Abingdon.

Truth and Reconciliation Commission (TRC) 1998. Truth and Reconciliation Commission of South Africa Report. Cape Town: Juta.

Van der Walt, B J 1999. Naby God: Christus en kerk op die drumpel van spiritualiteit. Potchefstroom: Potchefstroomse Universiteit vir Christelike Hoër Onderwys.

Villa-Vicencio, C 1988. Theology and violence: The South African debate. Grand Rapids, Ml: Eerdmans.

Villa-Vicencio, C 1994. Are we still of use?: A question of social significance, in Du Toit, C W (ed). Sociopolitical challenges to Christianity in South Africa, 95110. Pretoria: University of South Africa.

Vorster, J M 1981a. Die kerk en die kleurvraagstuk vandag. Braamfontein: De Jongh.

Vorster, J M 1981b. Die kruis of die vuis?: Kerk en rewolusie in Suid-Afrika. Pretoria: Gereformeerde Kerk Derdepoort.

Vorster, J M 2004. The attitude of Christ as a principle for modern Christian ethics seen from a classic Reformed perspective. Studia Historiae Ecclesiasticae 30(2), 48-73.

United Nations' Non-Governmental Liaison Servics (NGLS) 2002. Voluntary approaches to corporate responsibility: Reading and resource guide. Geneva: United Nations.

United Nations 2003. Intergovernmental negotiations and decision making at the United Nations: A guide. Geneva: United Nations. 